\title{
Outputs of EU 7th Framework Programme Research on Security at Major Events Focused on Private Security Services
}

\author{
Jozef Meteňko \\ Department of Criminalistics \& Forensic Science, Academy of the Police Force in Bratislava, Slovakia
}

Copyright $\bigcirc 2016$ by authors, all rights reserved. Authors agree that this article remains permanently open access under the terms of the Creative Commons Attribution License 4.0 International License

\begin{abstract}
Purpose - The study aims to look at the best practices and research outputs of private security services in the field of protection of persons and property at major events. This study presents some outputs of research projects EU SEC II - VÝSK. 173, GODIAC - VÝSK. 171 and THE HOUSE - VÝSK. 172. Design/Methods/Approach - To gain the outputs of the three conducted projects, the actual police and security reality was tested while applying practice-oriented research methods, such as planning, modelling and its testing on practical events, direct and indirect observation, explorative methods, in particular a questionnaire and recording techniques, and their evaluation with the use of statistical methods to determine the homogeneity and reliability of the results of qualitative investigation. Findings - The research projects carried out in terms of FP7 present the results which in this direction bring many consequences for cooperation between states, municipal and private security services and its tasks. Research limitations/Implications (if applicable) - The existing legislation in countries of Europe offers several alternative solutions to the issues by using the private security service. Each of the solutions has its limitation arising mainly from the local legislation and national organisation of security services. Practical implications (if applicable) - The study has outcomes and implications for police practice and management in securing major events. Visible applications and consequences have been identified for security planning and controlling, published especially in parts 4 and 5 of this study. Originality/Value - This study is an original debut and the first presentation of the conducted 7 th FP research in the section on private security. The study is intended for theoreticians in police sciences, as well as security and police practitioners, in particular police management, security measures planners and management of private security agencies.
\end{abstract}

Keywords Protection of Persons and Property, Municipal Police, Private Security Service, Security Sustainability

\section{Introduction}

The Academy of the Police Force in Bratislava represents the Slovak Republic in various European scientific projects, including some based on calls from the 7th Framework Programme. The House project is a regional European platform for the coordination of major events security research in Europe. The project, which involves $24 \mathrm{EU}$ member states, was implemented from March 2012 until February 2014. It was a follow-up project of EU-SEC and EU-SEC II, the projects funded by the European Commission. [6]

Coordinated by the United Nations Interregional Crime and Justice Research Institute (hereinafter referred to as UNICRI), the project aims to achieve coordination in security planning of major events in Europe, and contribute towards the adoption of a common policing approach at the European Union level. UNICRI was established in 1967 to support the member states in the areas of crime prevention and criminal justice. In furtherance of its mandate, UNICRI uses the action-oriented research to assist in formulation of improved policies and particular intervention programmes. Against this backdrop, UNICRI identifies the areas of common concern to member states which are of critical importance to the international community in general upon which to concentrate. Security planning for major events is one such area. [3]

The purpose of GODIAC, another of the above-mentioned projects [9], was to identify and distribute good practices for a dialogue and communication as strategic principles in managing and preventing public disorder at political manifestations in order to uphold fundamental human rights and to increase the public safety at these occasions and in general. GODIAC finished in May 2013 after three years of cooperation between 25 partners from $14 \mathrm{EU}$ countries, and was managed by the Swedish National Police Board. 


\section{Major Events}

Major events are often accompanied with substantial increase in financial, human, technological, and other resources available to national security planners. From the point of view of security organisations, major events are windows of opportunities due to the fact that they can improve the understanding of the lines and tasks for all involved security organisations. As a result, major events offer the finance and availability of resources to expand a modern and efficient security infrastructure, which allows for increased security while requiring decreased levels of policing. Additionally, major events allow for the introduction of systems and practices, procurement of equipment and expertise, development of training and expansion of capacity in the manner that is innovative and meaningful. This way they provide the legacy of development in national security planning practices and structures, as well as new forms of thinking in response to emerging threats for the national security, and the furherance of international cooperation among security planners [3]. Major events have unquestionable importance to national and multinational components ensuring all activities, including security. [1]. However, major events affect local security to the greatest extent [4] and just maximize the burden of local self-government and security structures [5]. This is reflected in traditional rules of liability for their control and management in continental Europe [2].

Having identified major events as an area in need of international coordination, UNICRI launched its global programme on major events in 2002. This programme subsequently received express backing from the United Nations Economic and Social Council (ECOSOC) Resolution 2006/28, in which the Council invited UNICRI to continue and expand its work in this area, and invited the member states to request UNICRI's assistance for the security planning of major events. A common thread throughout the UNICRI's work is the focus on activities at regional level. That stems from the recognition that programmes and projects implemented within countries of similar social, political, and economic background and institutional frameworks can be carried out more effectively and the legacy of success can be seen throughout the region. Based on this approach, the project EU-SEC was initiated by UNICRI in 2004, as the first regional platform for the coordination of security during major events in Europe. Subsequently, in 2007 UNICRI launched a similar regional platform for the coordination of major events security in the Americas. [14]

\subsection{EU- SEC and EU-SEC II}

EU-SEC, which involved 10 EU member states, was funded by the European Commission's $6^{\text {th }}$ Framework Programme - DG Enterprise and Industry. It was aimed to supporting and coordinating national research activities related to security during major events. EU-SEC pioneered a common methodology for the coordination of national research programmes on security during major events at European level. In addition, the project developed research on police ethics and public private partnerships during the planning of major events, and it identified the thematic priorities for future research activities all of which were to be built upon later in EU-SEC II. Furthermore, by establishing a coordination platform of end-users, EU-SEC laid the foundations for the creation of "the European House of Major Events Security". In researching major event security programmes in Europe over the last ten years, EU-SEC reviewed its working definition of a "major event". First formulated in early 2005 for the survey purposes and later revised for the purposes of the 2007 IPO Security Planning Model [12], it was again reviewed at the 5th EU-SEC II Network Steering Committee meeting in Stockholm on 26 January 2011 for the purpose of its use within this manual and the House (see next page).

Based on this success, the follow-up project EU-SEC II funded by the European Commission's 7th Framework Programme - DG Enterprise and Industry was launched in 2008, involving 22 member states. EU-SEC II identified the key areas of security planning for major events which required further coordination. Based on that, a number of standards and priorities for future research [3] were defined and/or elaborated. 


\section{AMAJOR EVENT IS AN EVENT}

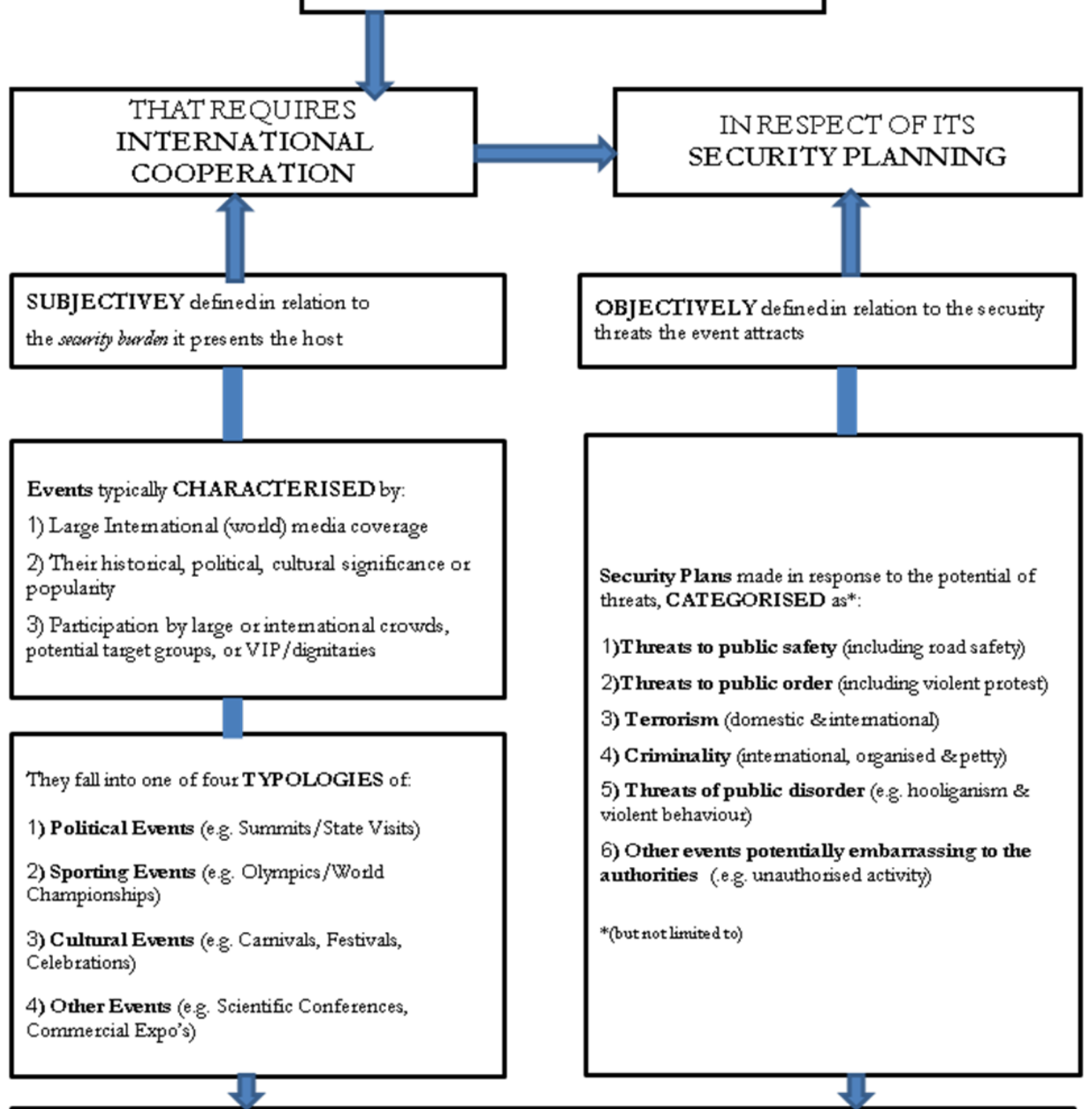

Generally recognisable in the field through the following QUALITIES or similar:

-For the host country their extra security requirement may be domestic or international

-They tend to be urban in character (if not location) as an expression of global society

-They may be regular or non-regular in spatial and/or temporaloccurrence

-They will tend to dominate other security planning concems

-Their security demand will be extra-ordinary and in excess of routine capacity

-They may produce new security measures that redefine routine policing for the host 
These standards and priorities were divided into two main groups: "Established Standards" and "Tools for Development". The project elaborated the established standards in relation to four areas:

- IPO Security Planning Model: A security planning can be tailored to each country's specific needs.

- Public Private Partnerships (PPPs): Guidelines for assessing, establishing and utilizing PPPs.

- Media Management: Guidelines for police and security planners in general on the cultivation and management of symbiotic relationships with the media.

- Ethical and Operational Standards for Security and Security Products: A tool used to review operational adherence to the Council of Europe's 'European Code of Police Ethics' and the quality assurance process of bringing any new security products into the daily routine.

Further three "Tools for Development" were defined as:

- Specialist Technical Equipment Pool (STEP) - a database of specialist technical equipment that partners will be able to share in order to support the planning and procurement decision.

- European Major Events Register (EMER) - a database or register that will allow registering events as "major" ones by hosting authorities.

- Training and Networking - to promote and raise awareness of "the House" service among EU police forces in collaboration with European Police College CEPOL.

The final output of EU-SEC II was the manual "Foundations of the European House of Major Events Security" and that brought the House into being. [14]

\section{The House Project [3]}

The House project ran from March 2012 to May 2014 and was funded by the European Commission's 7th Framework Programme - DG Enterprise and Industry. The project was launched to test the standards which had been outlined in EU-SEC II as common EU standards. Similarly to the preceding project, the House showed expansion in the Consortium of $24 \mathrm{EU}$ member states.

In the process of "testing" the standards as common EU standards, the participating project partners attended the "associated events" and discussed the standards of the House in relation to the accepted national practices. After the consultation process with the project partners during which over 30 major events were considered, eight major events were chosen. Particular importance was attached to achieve a balance among sport competitions, mass gatherings and political summits due to the fact that the challenge presented to security planners by each of these events differs greatly. The House tested its standards at the following events:

Euro Athletic Championships, Finland, June - July 2012

UEFA Euro Cup, Poland, June - July 2012
Bulgaria - Italy FIFA WC Qualification, Bulgaria, September 2012

EU Presidency, Ireland, January - June 2013

Rainbow March, Slovakia, September 2013

EU Presidency, Lithuania, June - December 2013

CEV Euro Volley, Poland, September 2013

Nuclear Safety Summit, the Netherlands, April 2014

The "association" of an event to the project required the project partners meeting with security planners of the chosen major events in order to present the standards of the House. The subsequent discussion/consultation process helped determine the gaps and/or overlaps between the House standards and those ones applied nationally. The dual goals of this process were, on the one hand, to assess the impact of the standards as common European planning and evaluation standards; on the other hand, to assess their potential impact on the main EU security priorities defined in "the Stockholm Programme and the EU Internal Security Strategy". The results of the consultation with national security planners were recorded and formed as a basis for final project reports. Based on those reports, a set of User Guidelines was drafted to complement the Manual published at the end of EU-SEC II; the guidelines contained practical information for major events security planners and other security practitioners on how to make full use of the House and its services.

A unique aspect of the House as a research project was that national end users from $24 \mathrm{EU}$ member states were the main actors/researchers in the project. They were appointed to various roles ranging from "Event Hosts" who organized and facilitated the consultation process with national security planners of associated events; "Standard Owners" who acted as "custodians" of a standard, presenting the standard to national security planners at the associated event meetings; to "Task Team Members" who attended the associated events gaining and recording feedback from the national security planners on the impact of the standards as common European planning and evaluation standards and on their potential impact of the main EU security priorities. This method of policy development which involves the security planners at all stages ensures that they and their countries are real owners of the output.

For the needs of "the House" the project defines a "major event" simply as "an event requiring international cooperation in respect of its security planning". The Olympics, G8 and EU summits typify such events and the challenging complexities of security planning related to them. This is particularly due to the cross-border international cooperation dynamics they present, the public delivery of which is regularly under the critical scrutiny of world media.

To help coordinate this area in the interest of developing an EU level of consistency, as well as improved security delivery, the EU-SEC II project resulted in the production/adoption of seven prototype "coordination tools/methodologies" (CTMs), or services, for future use by EU member states in relation to planning for such international events. 
They are as follows [14]:

CTM 1 - The IPO Security Planning Model: A model that can be used as a common benchmark and checklist/evaluation tool by national authorities in respect of their own planning. Developed by UNICRI, it has been successfully-field tested during the project in fields.

CTM 2 - Best Practices in Public-Private Partnerships: A common guidance document for assessing and establishing good practices and core principles in relation to the division of responsibilities and the regulation of private sector involvement in security planning.

CTM 3 - Media Management Guidelines: Closely connected to and building upon ethical considerations in relation to major event security, guides planners towards the importance of international consistency and professionalism in police press-office management.

CTM 4 - Ethical and Operational Standards for Security Products: A set of statements that contextualize and reflect compliance to relevant aspects of the Council of Europe's European Code of Police Ethics as a common set of professional standards to reflect upon and promote.

These four serve as common House policies in relation to planning and evaluation activities. The remaining three serve as common House tools for coordinating up-to-date research, technologies and training in relation to major event security planning at EU level:

CTM 5 - Specialist Technical Equipment Pool (STEP): A database to support planning and procurement decisions by storing availability/reviews of required technical resources. Cooperation on information sharing for this tool was successfully tested during EU-SEC II.

CTM 6 - European Major Events Register (EMER): For common registration of an event as 'major' by a hosting authority, its recognition as such by the House and the medium through which to access House services. It will also build up longer-term research data.

CTM 7 - Training \& Networking: Modules and curriculums on major events security standards in collaboration with the European Police College (CEPOL). It raises awareness and promotes the use of House services among relevant national policy makers and practitioners.

Chapters of the Manual [6] describe each CTM in detail. The supporting chapters detail the project's EU-wide survey and its findings in relation to the state of international security research and planning coordination among national authorities over major events and potential legal/cultural obstacles to continued and future international cooperation in respect of it.

In finding a general need and opportunity to develop a commonality of policing in Europe through major event security planning, it also found that there were no significant legal or cultural obstacles to move in that direction. In particular, the EU's 2008 Prüm Decision was found to be a potentially supportive European level legal instrument in need of monitoring. Consequently the project's strategic roadmap, detailed towards the end of this manual, emphasizes the importance of the continued commitment of national authorities to the building of the House and their ownership of its CTMs under the EU-SEC programme.

\section{The IPO Security Planning Model (at CTM 1)}

Launched in 2003 as a global security and counter-terrorism programme, the International Permanent Observatory (IPO) on Security during Major Events was built upon three core considerations relating to the phenomena of Major Events:

Complexity: that their security planning challenges should not be underestimated.

Legacy: that they present opportunities to expand and introduce lasting security capacities.

Scarcity: that knowledge and expertise on their planning is rare, diffuse and hard to access - spread between disparate authorities of different countries with various restrictions on access. [6]

Drawing on the collective experiences of security planners for major events in Europe, the 2007 IPO Security Planning Model (building on the 2005 Security Planner's Toolkit) fulfils the need subsequently identified by member states for an internationally recognized security manual as a common standard covering the main elements of the planning process and guiding principles of security provision at Major Events. As an evolving House resource based upon best practices and lessons learnt in that collective experience, the IPO Model therefore represents an international planning and evaluation standard: a common benchmark, or template, against which the member states can review and evaluate their own standard national research programmes and planning processes for major event security. That is, to see it as a process rather than a plan. [12]

This reflected an important point raised in the UK team's Task 3.1 report: to be mindful of national initiatives among EU member states to develop their own Major Event Security Manuals and current use by many of their own standard operating procedures for major event security and ensure compatibility between them and that of the House. To this end, the idea was not to replace the national models (e.g. the UK's SECCO Manual) but to use the IPO Model as a common point of international comparison in respect of them and their development. These concerns were also reflected in the Task 3.4 presented as Strategic Roadmap, which pointed out the likelihood of structural resistance to paradigmatic changes of practice and doctrine amongst national authorities.

\subsection{Basic Description of the Model}

Unlike the 2005 planner's Toolkit, the 2007 planning Model is not a practitioner's technical manual, but a policy maker's (or security manager's) checklist for managing the security planning process of a Major Event. Set against a 
description of twelve main elements of a security planning process (ranging from leadership and structural management to contingency planning and crisis management), the model consists of three main components: a system (for organizing those involved in the planning); the deliverables (of security and contingency plans); and risks (of anything that may adversely challenge the plans).

This is not the place to detail the content of either the Toolkit or the Model. However, the Model can be summed up as: a system that produces deliverables to address the existing and potential risk. The system covers issues concerning capacity, constraints and intelligence.

The deliverables focus on plans for both inside and outside of the security venue, along with 'if' contingencies. The five 'risks' spoken of in the IPO Model (terrorism, public disorder, crime, image embarrassment, emergencies) as a combination of 'threats' and 'vulnerabilities' detailed in the Toolkit, were echoed in the House's six 'threat' potentials to a major event.

\subsection{House Development of the Model [14]}

Among the EU-SEC Consortium, there was overwhelming support for the national incorporation of the IPO Security Planning Model and its common recognition among practitioners as a basic template for reviewing and developing local security plans. How to best achieve its national recognition and local acceptance among security planners throughout the EU was a consideration of Task 3.2 during 2009.

Under Austria's (+ Ireland and Italy) lead, the task team reported on a phased approach involving the following sequential steps as the best way to achieve this aim:

a presentation of the IPO Model to each member state;

a table top exercise in its use at national training level;

a local field exercise in its operational use with a small routine event;

a feedback review and evaluation of its field-tested.

To do this, the following basic actions were needed to be carried out in preparation:

1. Seek recognition of the IPO Model at an appropriate level within member states

(i.e. the executive or senior management).

\section{Introduce it into national training programmes} where appropriate

(i.e. as core training, promotion/specialist courses or as professional development programmes).

\section{Develop a 'train the trainer' programme}

(i.e. to ensure continuity and consistency of delivery in each member state).

\section{General dissemination within member states}

(i.e. ensure availability in all police libraries and personal issue to those working in security planning).

With regard to the Networking and Training CTM 7 and its development within the House under the third phase of the
EU-SEC programme, the Austrian task team determined that the potential of pursuing such a programme through CEPOL (European Police College) should be considered by respective task leaders with the dissemination of resulting reports coordinated by UNICRI. The Romanian partners further endorsed its use in police training curricula as a significant tool. To this end, the above approach is offered as a suggested guide for future House development.

\subsection{Field Testing and Ownership}

The field testing of the IPO Model was one of the ideas accepted by the EU-SEC Consortium in December 2006 for future joint activity. In June 2007 UNICRI presented the model to security planning specialists and other EU-SEC partners at the Police College of Finland. It was found to closely match the domestic models and gained a constructive feedback. In standing up to scrutiny in this way, it was viewed as representing a robust standard that provides a checklist for existing plans and backbone for future evaluations. Indeed, during 2009 and as part of Task 3.2, the 2007 IPO Model was successfully-field tested by Denmark in relation to the Copenhagen Climate Change Summit (COP 2009) in December that year. From the COP 2009 field-test experience, and as provisional CTM Owners of the IPO Model for the House, the Centre for Policy Studies in Denmark produced an 'IPO Security Planning \& Evaluation Checklist' to be used in conjunction with future joint activities in this area. For ease of reference, the checklist is reproduced at the end of this chapter.

With regard to two other CTMs that follow, guidelines on public-private partnerships (PPPs) and media management in respect to Major Event security planning, they should be seen as interfacing with related elements of the IPO Model: namely that of the first element 'Leadership' and the fourth element 'Media \& PR Strategy' respectively. Finally, in 2009 the Denmark Centre for Police Studies presented IPO Security Planning and Evaluation checklist:

\section{Element 1: Leadership}

All involved properly understand the chain of command

All involved properly understand their specific responsibilities

\section{Element 2: Planning Structure and Management}

Planning team identifies main branches for planning.

Base planning identifies best practices and evaluation of previous events.

\section{Element 3: Intelligence}

Threat assessment: "What is the likelihood?"

Vulnerability assessment: "What are the consequences?"

Risk assessment: Likelihood X Consequences = RISK

\section{Element 4: Media \& PR Strategy}

Media monitoring

Design of public information strategy 
Public reassurance - explanation of momentarily variations from "normal"

\author{
V. Element 5: Venue Security \\ Harden secure area \\ Search, seal, secure \\ Maintain public safety \\ Vetting/Accreditation/ticketing \\ Access control
}

\section{Element 6: Border control}

Strengthen routine border control

Intelligence-led strengthening ASAP

Enhance information sharing and collection

\author{
VII. Element 7: Traffic Management \\ Maintain and secure access routes \\ Maintain and secure road network in and beyond secure \\ area
}

Design proportionate public transport

Prepare for disruption and blockage of routes

VIII. Element 8: Non-Event and Event-Related Security

Plan to protect people and property

Plan for event-related sites

Plan for critical infrastructure

Plan for "soft" targets

Promote stakeholder awareness

Design early warning mechanisms

\section{Element 9: Human Resources and Logistical Support}

Support strategy with adequate personnel

Provide adequate logistical support

Enhance human response with equipment and technological solutions

Plan for withdrawal and return to normality

\section{Element 10: Information Technology (IT) and Communication}

Design effective and secure communication

Design appropriate and comprehensive control centres

Design comprehensive flow-charts showing lines of communication and management of data

Design protection of core communication and plan for communication in emergencies

\section{Element 11: Integration and Coordination}

Integrate, complement and coordinate all planning branches

Test flexibility and effectiveness of plans

Test competence of individuals and teams

Test equipment in prevailing surroundings

\section{Element 12: Contingency Planning and Crisis Management}

Design contingency plans

Plans shall: Save and protect, prevent further development of emergency, maintain critical services, inform media and restore to normal ASAP while facilitating investigation

XIII. Additional Elements to be evaluated?

\section{Public-Private Partnerships - Best Practices as Guidelines for Assessing, Establishing and Utilizing PPPs (at CTM 2). [14]}

The aim of this methodology used in the project as a coordination tool was the common guidance on establishing best practices with public-private partnerships (PPP) within national and international EU frameworks as a part of the overall planning process. It complements the Leadership element of the IPO Security Planning Model, particularly with regard to its guidance on establishing common standards for contractual agreements between parties national security services, local security services and private security services (PSS) - to PPPs at Major Events. [8]

The project work led by the Metropolitan Police resulted in two key documents being produced with regard to this CTM: Report on Public-Private Partnerships in Major Event Security in the EU, and its end product, the Practitioner's Guide to Public-Private Partnerships for Security at Major Events. Via seven thematic areas, the practitioner's guide provides thirty recommended phases/elements for consideration as 'best practice' in the security planning process. They were arrived at by a comprehensive review of EU Major Event Security Manuals and published studies of private security industry and police interactions in the EU and practitioner evaluation surveys among EU-SEC partners and UK Security Coordinators (SECCO's). They represent a practitioner's consensus on a "best practice". As a foundational service of the House, the overall intention was to test their application as common planning standards in respect of PPPs to help coordinate international cooperation in this area.

What was envisaged in the House's future testing of this CTM was the development of a database of best practice partnerships provided by member states, including a list of companies already in similar partnerships and their fields of expertise. For the House project, the UK report emphasized the importance of the "replicable" criterion in that the adoption/adaption of a practice should not depend too much on substantial resource inputs, unique legislative frameworks, involvement of individual personalities or other special circumstances: in short, easy application across all $27 \mathrm{EU}$ member states. This is not the place to detail the content of the PPP guidance itself. A summary checklist of the thematically grouped elements appears at the end of this part of study on PPP.

\subsection{Core Principles - Responsibility and Regulation for PPP}

With regard to major event security in the EU, 
public-private partnerships can be understood as being built upon some core principles concerning responsibility and regulation.

First, the Major Event Organizer (MEO) is primarily responsible to security at the event, regardless of the public or private nature of the venue, or event itself. Accordingly, the common expectation of police duties in relation to the event is their response to security threats that are beyond the management capacity of the organizer: in other words, that which the Private Security Industry (PSI) cannot presently provide for. [8] This core principle is explicitly stated in the EU Council's 2007 Handbook for police and security authorities concerning cooperation at Major Events with an international dimension (EU Doc. 10589/1/07, REV 1, ENFOPOL 119, Brussels, 4/7/07). And this note recommends ensuring compatibility between what this IPO Model is as a House CTM and national initiatives now being undertaken to develop similar MES Manuals. For example, the UK SECCO Manual's approach to the risk management in relation to MES based on principles of reduction to an acceptable level rather than absolutes of prevention.

The second core principle stressed in the UK report is that of only using regulated private security companies or companies that employ security personnel holding state recognized licenses. The report divides the private security into four categories: 1) Private Security Industry (PSI) standard provision of trained security personnel; 2) Private Military and Security Companies (PMSC) - exceptional provision of armed security; 3) Hired Police Services provision of police services to MEO at cost; 4) Private Citizens - provision of volunteer/paid stewards for safety (not security) duties. The report found that (in 2009) there was still no consensus in EU countries regarding the nature of partnerships with the private security industry in MES. This is despite of PPPs becoming an increasingly established feature of security in EU member states. This is to the point of becoming 'institutionalised' in the eyes of the European Commission by virtue of their operation over very long periods of time to cover for the reduced role of the state in some areas of security provision in the last few decades. [10].

These principles are applied even though House services are more concerned with temporary PPP arrangements in relation to MES. The report's further review of EU Major Event security policy and general commentary on public-private security sector relations is covered more substantially here in respect of these two areas of core understanding.

\subsection{On Responsibilities - EU Major Event Security Policy}

The UK report points out that the Amsterdam Treaty (in force since $1^{\text {st }}$ May 1999) introduced the aim of making the EU a single 'area of freedom, security and justice'. Its implication is that wherever an individual is in the EU they should enjoy a common standard of policing and security. In contrast to hitherto international cooperation agreements over public order policing and intelligence sharing since the mid-1970s that left domestic and national policing largely unchanged (i.e. football hooliganism and related police intelligence sharing since 1975 TREVI), the Amsterdam objective now creates both obligations and expectations of a domestic change towards a commonality among national authorities in respect of the domestic and national delivery of policing as a public good in EU states.

Citing a number of EU policy development during the 1990s on establishing key principles and issues in international public order and security cooperation, and echoing the question of balance theme alluded to in the introduction of this manual for the House, the report points to two such public order principles set out in the European Council's 2002 'Security Handbook for the use of police authorities and services at international events such as meetings of the European Council':

1. that "The enforcement of law and order should be guided by the principles of proportionality and moderation preferring the less intrusive approach. Where possible, a de-escalating police approach should be chosen"; and

2. that "Dialogue and cooperation with demonstrators and activists should be actively pursued by the police authorities."

The implementation requirement, the report continues, is for each member state to have a 'national contact point' to collect, exchange, and disseminate information and risk analyses. [10].

"Although the host Member State has primary responsibility for providing for the security at the event, given its international character, all other member states and EU competent bodies have a responsibility to assist and support the provision of such security." (see MetPo, 2010, p. $9,[10])$.

Where the EU's European Police Chief's Task Force (founded in 2000 for high level information exchange on European policing issues and practices) is said to have paid little direct attention to MES as a specific topic, the UK report also notes that from an EU security research perspective the 2009 European Security Research Innovation Forum's (ESRIF) Final Report recognizes Major Events precisely as "valuable laboratories to implement and test specific security measures as well as elaborate best practices that are also transferable as routine protective measures for fixed targets." In other words, significant test-sites for research based innovations and transformations in European policing and security.

In this context, the House's testing and development of its practitioner's guidance to PPPs through MES takes place with a view to coordinating a common understanding as to the nature of the relationship between public and private partner responsibilities. In particular, based upon a 2007 UNICRI brainstorming meeting [10], that: 
- at the macro level, security strategies are designed to protect the wider community and not simply the interests of the partners involved;

- at the mezo-level, those with management responsibilities in the partnerships have authority to take decisions and commit resources on behalf of their organizations; and

- at the micro-level (i.e. the event itself) that all parties have an information sharing protocol in place.

The developing relationship between public and private sector security over areas of responsibility thus represents significant new ground in Europe and should be commented upon a little further.

\subsection{On Regulation - Public-Private Security Sector Relations}

Traditionally the Private Security Industry (PSI) typically took the form of guarding services for corporate premises or escorted secure high value transportation services. Its personnel might be armed (depending on the laws of a particular state) but in serving primarily private rather than state security interests they did not commonly possess more police powers than an ordinary citizen of the state. Growth since the $1980 \mathrm{~s}$, however, and particularly since the post 9/11 counter-terrorism concerns of the millennium, has seen the industry enter into areas of state interest security provision in Europe, albeit as secondary sources of provision to that of the state itself. With specific regard to major event security though, the research team indicated that the public sector tended to assume that it was actually the private sector that acts as the primary source of protection at an event's location, not the police. One can refer here to the related glossary terms "mass private property" and "privatisation" being used in the academic police studies literature.

What the report usefully noted in debate over the relationship of private security industry to state security interests was that the EU had made a bureaucratic "pillar location choice" around 2007 of moving the public-private security dossier from the "Third Pillar" of DG Justice Freedom and Security to the "First Pillar" of DG Enterprise and Industry. In other words, private security is currently seen within the EU more in terms of commerce than security as it previously was. A 2006-2008 EC funded study that this observation drew on also showed that (as within the eyes of European Police Chiefs) major event security as a specific area of PPPs was not highly visible in comparison to other, more traditional, areas of private security provision. The EU's pillar re-location further underscores the importance of House coordination in respect of common approaches to PPPs among EU member states.

To this end the UK report suggested the House to consider exploring links with the Confederation of European Security Services (CoESS). CoESS was founded in 1989 by national associations of private security companies in EU member states to represent and ensure their interests through work aimed at the harmonization of national legislation concerning the industry and its activities [15]. Research report noted that with one or two earlier exceptions there had been industry regulation in most EU and other democratic states since around the time of CoESS's foundation and that most (but not all) EU member states tend to regulate the industry under an interior-type ministry. This suggests, according to the study, either recognition of the industry's semi-policing type role or a desire to distinguish between public and private sector security functions [10].

What can be noted in relation to House interests in this area is the already multinational and increasingly global scale of Europe's major private security companies (such as Securitas $A B$ and G4S) and that the provision of crowd control and event security was ranked the second most common PSI function after traditional activities among the EU-25 states in a 2007 industry wide study by leading industry figure, Jorma Hakala. Study of 25 EU member states modified inputs during 2009 from EU-SEC II partners, the powers of security personnel either equalled or, in 13 out of the 26 EU States listed in report, now actually exceeded that of a citizen [10].

With the exception of the UK (regulations individuals rather than companies) compulsory regulation of PSI companies is the norm among EU member states. The report referred to studies presenting the Spanish regulatory regime as indicative of a security system most clearly exemplifying the integration of private security with public security. This is because there is no legal space within the Spanish constitution for private security provision, so regulatory measures have to be all encompassing and are claimed to be the widest in the Western world. In the UK, with comparatively far greater legal space for private security, integration is just as evident where government policy is reported to treat licensed and regulated private security industry services as part of what is referred to as 'the extended police family', despite variable support for this view among the UK police themselves.

\subsection{The Politics of Contemporary Security Provision}

Strong cultural and professional ties may well exist between private security specialists and public law enforcers, due to occupational mobility between them and increasing convergence of common interests. This observation may be tempered, however, with the report's own survey findings of what it described as a 'lukewarm' attitude by responding House members to the essential need for PSI services in PPPs for Major Event security. This was attributed to sensitivity about needing to stress the police as the primary national security providers, along with variables as to the (current) capabilities of the PSI in member states and variable experiences of the PSI at particular Major Events. [7].

In this respect, it might be important for the House to monitor changes over the time in the lines of demarcation between public and private forms of security provision in 
areas that may have traditionally been thought as 'public. That is, not to consider these lines as static lines but migratory and thereby as sites of gradual change and observable growth and expansion of new modes of policing and security provision within contemporary Europe. Changes brought about, in no small part, by what we are generally recognizing as 'Major Events' and what other researchers now recognize as the state's 'showcasing of security'.

As with the IPO Model, CEPOL lends itself as an appropriate European level senior police officer forum for further discussion and dissemination of knowledge on PPPs in the context of Major Events and questions of state regulation, legitimacy and supranational governance. Task 3.4 Report (Draft Strategic Roadmap) also comments on the use of monitoring the numerous legal problems that can occur in the case of Major Events even though daily contact and interaction between to private and public spheres of policing is now common. [6].

\subsection{Summary of Recommendations for PPP Guidance} [6]:

\section{A. Roles, Responsibility and Accountability}

1. Define who is accountable for the major event.

2. Define the relationship between the event owner (client)/event organiser/suppliers/ contractors/supporting agencies (police/private security/local councils).

3. Establish strategic lead.

4. Establish who the stakeholders are.

5. Establish Joint Command / Executive Planning Team.

B. Setting the Baseline / Strategic Intention

6. Intelligence requirement / threat assessment.

7. Define scope/footprint of event area.

8. Set initial strategic/executive meeting.

9. Set strategic intention.

\section{Agreeing the Parameters}

10. Define areas of responsibility and Agree Memorandum of Understanding.

11. Asset and resource assessment.

12. Budget setting agreement.

13. Agree information / intelligence / communication sharing protocol.

14. Form Security Committee/Security director/Security Integrator/ Police Security Coordinator.

\section{Consultation and Development of the Plan}

15. Stakeholder / Community Consultation / media engagement.

16. Media engagement.

17. Create security plan (Create tactical plans).

18. Review of security plan (by security committee).

19. All Plans (tactical and security) submitted to 'Gold' Commander or Senior Event Executive

\section{E. Preparedness}

20. Identify training needs.

21. Table top exercise / Dry run.

22. Identify contingencies.

23. Agree Joint Media Strategy.

\section{F. Review}

24. Review threat assessment and intelligence requirement.

25. Review of overarching plan (tactical and security plans) by Gold-feedback refine agree

26. Final Executive/Gold Planning meeting.

G. Event Day and Organisational Learning

27. Briefings

28. Live event - On-site Management

29. Hot de-brief.

30. Structured de-brief / lessons learnt / organisational learning

\section{The Future}

The 24 member states of the House have decided that the way forward should involve the development of an all-encompassing interactive web based security planning tool incorporating all methodologies and technical tools of the House. In this phase, the consortium will attempt to ensure that its pattern of expansion continues beyond the current 24 member states. As in the previous phases of the project, the involvement of the national security planners will be essential to ensure that the outputs will have the approval of, and will be adopted by, the partner member states. In addition, the consortium will work to consolidate the position of the House as a comprehensive European planning framework for major events security in order to ensure that established best practices are continually codified, and that lessons learned from major events in the EU are easily accessible to and serve to benefit the security of the entire community.

On a national level, our country benefits from similar projects in the long term. For the last three years we have taken part in GODIAC project. [11]. It was more typical for this research project to explore the relevance of communication and its application in order to overcome confrontation related to social understanding interactions for major events. The basic results of the project GODIAC "Good practice for dialogue and communication as strategic principles for policing political manifestations in Europe" include: greater harmonization of security policy regarding major events and overall common policing approach and interaction. [7] The purpose of the project is to identify and spread good practice for a dialogue and communication as strategic principles in managing and preventing public disorder at political manifestations in order to uphold fundamental human rights and to increase public safety at these occasions and in general. The overall idea of the 
project is to integrate operative police work, research and training within the field and to build international and institutional networks. [9]

In the broader sense, the method of policy elaboration applied by projects could easily be adapted to other contexts and other regions of the world with the assistance of the researcher, including UNICRI and their given role in regional policy coordination for major events security at United Nations level.

\section{Conclusions}

The House and GODIAC projects and their predecessors, EU-SEC and EU-SEC II, have made, and continue to make, a significant contribution to the coordination of European major event security planning. The objective of the partners is to create a lasting legacy of improved security capacity, common standards and procedures, efficiency, and increased regional and international cooperation among security practitioners especially in the field of communication. In this way, the windows of opportunity offered by major events will take advantage of the fullest extent of the security of the event itself, the maximization of the enjoyment of the event for all and the potential for development of security policies, practices and cooperation especially in area cooperation with private security services.

In the view of long term, the maintenance and expansion of the networks of security practitioners, methodologies and technical tools will ensure that the impact of projects goes far beyond major events security, as it contributes to the use of private security services as the main security priority of the EU - the Stockholm Program and the EU Internal Security Strategy (ISS) which calls for "more effective European law enforcement cooperation."

This study presents some outputs from research projects EU SEC II - VÝSK. 173, GODIAC - VÝSK. 171 and the HOUSE - VÝSK. 172.

\section{REFERENCES}

[1] Bílý, J., Kavan, Š., Svatoš, R., et al. (2013) Veřejná správa a bezpečnost státu jako součást udržitelného rozvoje, Vysoká škola evropských a regionálních studií. České Budějovice, 2013, 208 p., ISBN 978-80-87472-48-4.

[2] Dušek, J. (2010) Faktory regionálního růstu a rozvoje (se zaměrením na spolupráci měst a obcí v Jihočeském kraji). 1. vydání. České Budějovice. Vysoká škola evropských a regionálních studií, o.p.s., 2010. 294 p. ISBN 978-80-86708-94-2.

[3] Foundations (2011) of the European House of Major Events Security. A Manual for the International Coordination of Major Events Security Research in Europe, Turin, 2011.
[4] Kř́ha, J. (2011) Ochrana místních záležitostí veřejného pořádku ve světle teritoriálních souvislostí - aktuální edukační př́ležitosti a výzvy II - monitoring stavu a dynamiky dílčí součinnostní veřejnopořadkové praxe, s. 230-232, ISSN 1214-4967. České Budějovice. In: Auspicia, 2011, 258 p., ISSN 1214-4967.

[5] Kříha, J. (2013) Význam součinnosti a spolupráce orgánů obce v oblasti zabezpečování místních záležitostí veřejného pořádku pro lokální prevenci kriminality, In: Zoubková, I., Firstová, J., et al. Kriminologie - aktuálni problémy. Praha: Policejní akademie České republiky v Praze, 2013. p. 221 -228, ISBN 978-80-7251-395-6.

[6] Metenko, J., (2012), Manuál - (verzia SK) Koordinovanie národného výskumu a politiky na zaistenie bezpečnosti pri významných udalostiach $v$ Európe EU SEC II: záverečná správa zahraničnej medzinárodnej vedeckovýskumnej úlohy: FP7 Grant Agreement (2008-2011). Bratislava: Akadémia Policajného zboru v Bratislave, 2012. 111 p. + 13 p. príloh. Výsk. 173.

[7] Metenko, J., (2013): The Possibility of Using Private Security Services in Slovakia to Ensure Local and State Public Order. In: The Anthology: GODIAC - Good practice for dialogue and communication as strategic principles for policing political manifestations in Europe. - Uppsala: 2013. - ISBN 978-91-86791-04-9. - p. 84-91.

[8] Metenko, J., Hejda, J., (2012) Alternatíva privátneho sektora a preventívnych policajných činností. Kap. 3.11, In: DUŚEK, J., PÁNA, L., SVATOŚ, R., a kol., Udržitelný rozvoj a funkce moderného státu, 1. vyd., České Budějovice: Vysoká škola evropských a regionálních studií, 2012, 368 s., ISBN 978-80-87472-20-0, p. 263-273.

[9] Metenko, J.,Misota, M., Hullová, M., (2012): Správna prax pre dialóg a komunikáciu, ako strategické principy policajných činností na politické manifestáciu v Európe (GODIAC): Priebežná správa $z$ medzinárodnej vedeckovýskumnej úlohy: Projekt financovaný EÚ (verzia SK). 1. vyd. - Bratislava: Akadémia PZ, 2012. - 46 p. VÝSK. 182.

[10] MetPo, (2010). EU-SEC II Task 3.1 Report. Public-Private Partnerships in Major Event Security in the EU - The search for 'best practice' or 'what works' in 'preventive partnerships'. (confidential). Turin, 2010, Italy: UNICRI.

[11] The Anthology, (2013): GODIAC - Good practice for dialogue and communication as strategic principles for policing political manifestations in Europe. Uppsala: 2013. ISBN 978-91-86791-04-9.

[12] UNICRI, (2007). IPO Security Planning Model. Turin, 2007, Italy: UNICRI.

[13] UNICRI, (2009). Toward a European House of Major Events Security. Turin, 2009, Italy: UNICRI.

[14] UNICRI, (2010). The House FP7 Project Proposal. Enhancing European Coordination for National Research Programmes in the Area of Security at Major Events. Turin, 2010, Italy: UNICRI.

[15] COESS, (2011). http://www.coess.org/objectives.htm (accessed 11 April 2011). 